\title{
Histochemical And Immunohistochemical Studies on The Effect Of Melatonin On Experimental Atherosclerosis In The Aorta of Rabbit
}

\author{
Mattar FE*; Ismael AA*; Kasem MA** and Ibrahim KI** \\ From the Department of Histology, Al-Azhar Faculty of Medicine in \\ Cairo* and in Assiut**
}

\begin{abstract}
Treatment of atherosclerosis or its prevention still represents one of the difficult challenges to modern medicine. Free radical peroxidation of LDL has been proposed to have a primary effect on the onset of diet-induced atherosclerosis. Melatonin has been shown to be potentially effective in prevention of some disorders in which free radical processes are involved. The purpose of this study was to investigate the possible protective effects of melatonin on high cholesterol fed animal arteries. Assessment of the atherosclerosis associated foam cells, intercellular adhesion molecule-1(ICAM-1) and vascular cell adhesion molecule-1 (VCAM-1) was performed by histochemical and immuno-histochemical methods.

Thirty adult male New Zealand rabbits were divided into three groups, ten animals each. Group-A served as control, group B\&C were fed $1 \%$ cholesterol-rich diet for 6 weeks. Animals of group-C were drenched, at night, $510 \mathrm{ml}$ saline solution containing $4.2 \mathrm{mg} / \mathrm{kg} /$ day melatonin. Frozen sections from the thoracic aorta were prepared for histochemical demonstration of peroxidase \& acid phosphatase enzyme activities, and immuno histochemical display of ICAM-1 \& VCAM-1. The enzyme activity and adhesion molecule expression were measured by computerized image analysis.

Accumulation of peroxidase \& acid phosphatase-rich foam cells was microscopically evident in the sub-endothelium of group-B arteries only. Enzyme activity and expression of ICAM-1 were significantly ( $p<0.0001)$ higher in group-B than group-C which was also higher than control, while VCAM-1 expression was significantly $(p \leq 0.013)$ higher in group-B than control which was higher $(p<0.00001)$ than group-C.

In conclusion, the results indicate that melatonin could potentially be beneficial in prevention of the food induced atherosclerotic lesions.
\end{abstract}

\section{INTRODUCTION}

Excluding the genetic factors, hyperlipidemia along with enhanced oxidation of lipoprotein lipids are separate but interacting factors giving rise to the formation of atherogenic lesions (Steinberg etal., 1989). Evidence in support of the lipid hypothesis is shown by the dramatic reduction in coronary artery disease arising particularly from cholesterol lowering drugs( Sevanian and Hodis, 1997). On the other hand, Oxidants have been shown to produce athero genic responses independent of lipid levels and the mechanisms of injury include many of the biological events described for atherogenesis. Support for the role of oxidants in the development of atherosclerosis also comes from clinical trials demonstrating antioxidant 
protection beyond that afforded by lipid lowering therapies (Hodis etal., 1995; Rapola etal., 1996). Sevanian and Hodis, (1997) reported the oxidantmediated processes thought to be of importance in early atherogenesis which included the following:

1) Increased VCAM-1 and ICAM-1 expression and monocyte adhesion protein.

2) The uptake of LDL via scavenger receptors produces dysregulation of intracellular cholesterol synthesis and cholesteryl ester accumulation leading to rapid lipid loading and foam cell formation (Berliner and Heinecke, 1996). These steps apply to the oxidation of serum lipoproteins as well as to vascular tissues. The role of lipop rotein lipid peroxidation appears to be central to this series of events since inhibition of peroxidation, or peroxide accumulation, tends to suppress, if not eliminate, the progression of atheros clerosis. Suppression of the atherogenic reaction to oxidants is mediated by several endogenous factors such as metal binding and antioxidant enzymes as well as by a number of antioxidant compounds.

Antioxidants have been shown to protect the cells from the free radical damage (Mattar and Moustafa 1995). An anti-atherosclerotic potential has been demonstrated primarily in animals with some antioxidants, these being probucol (Daugherty et al., 1989; Hodis et al,1992), vitamin E (Wojcicki et al. 1991 ; Kleinveld et al.,1995 ; Verlangieri et al., 1992), vitamin E and C (Bocan et al., 1992 ) and vitamin C (Beetens etal.1984). Some epidemiolo gical (Bellizi et al.,1994 ; Stampfer and rimm et al.,1995 ; Gey et al., 1987; Rimm et al.,1996 ) and clinical (Rapola et al.,1996) studies tended to confirm the results of animal experiments. However, recent, very large, carefully conducted clinical intervention trials using adequate doses of vitamin $\mathrm{E}$ demonstrated no effect on a composite endpoint of non-fatal infarction, stroke or death from cardiovascular causes (Steinberg, 2000). One of the compo unds that are considered as having antioxidant action is the pineal secretory product, melatonin (Goodman \& Gilman's, 1990). Melatonin is a horm one that has beside its antioxidant acti vity, several other biological effects. Melatonin was reported to regulate the expression of cell adhesion molecules which is one of atherosclerosis -associ ated features. Impaired nocturnal secretion of melatonin was reported to be associated with coronary heart disease (Brugger, et al., 1995). Sakotnik, et al., (1999) postulated that melatonin production may be impaired, due to a lack of synthesizing enzyme, in patients with coronary artery disease. So, decreased melatonin level may be a predisposing factor for coronary artery disease, or the occurrence of coronary artery disease decreases melatonin synthesis.

The aim of this study is, therefore, to reveal the possible protective effect of melatonin on diet-induced atheroscl erosis in rabbits. Quantitative immuno histochemical and histochemical method were used to evaluate the expressivity of VCAM-1 and ICAM-1 as well as the accumulation of foam cells as parameters for atherosclerotic manifestation. Such data may add more insight for understanding the cellular and molecular mechanisms of atherosc lerosis, and possibly its prevention and treatment.

\section{MATERIAL AND METHODS Material}

Adult male New Zealand rabbit was the animal of choice because it is the most sensitive species for induction of 
atherosclerosis. The female rabbits were not used to avoid the effect of the cyclic physiologic hormonal changes. The rabbits were about 12 week old. The animals were divided into three groups each of 10 animals.

\section{Group-A: (Control group)}

Animals were raised on ordinary, cholesterol-free, diet for 6 weeks.

\section{Group-B (Atherosclerotic group)}

Animals were raised on the ordinary diet mixed with $1 \%$ cholesterol powder for a period of 6 weeks (Fennessy, etal., 1994). The cholesterol powder used was produced by Merck Company in Germany. Each bottle contained 25 grams yellow cholesterol powder of good quality.

\section{Group-C (Melatonin treated athero - sclerotic group)}

Animals were raised on the ordinary diet mixed with $1 \%$ cholesterol powder (Fennessy, etal., 1994) and were drenched, by naso-gastric tube, $10 \mathrm{ml}$ solution containing $4.2 \mathrm{mg}$ Purified pharmaceutical grade melatonin (Memphis Co. For Pharm. \& Chem. Ind. Cairo), dissolved in saline every night for 6 weeks. The total daily dose was calculated according to Paget \& Barnes(1964).

Monoclonal antibodies of (VCAM-1) and (ICAM-1) were a generous gift from Dr. M. Cybulsky (Department of Laboratory Medicine and Pathobiology, University of Toronto, Canada).

\section{Methods}

Frozen sections of $10 \mu \mathrm{m}$ thickness were prepared. Sections of the control and other groups were mounted on the same slide. Sections were stained by the following techniques:
I-Histochemical Techniques for demonstration of foam cells:

(1)Diaminobenzidine method; for peroxidase in peroxysomes (Carleton, 1980).

(2)Lead phosphate technique; for demonstration of acid phosphatase enzyme activity in lysosomes (Pearce, 1972).

\section{II- Immuno-peroxidase Technique:}

ICAM-1\&VCAM-1 were demonstrated by the immunoperoxidase method described by Dako manufactural instru ctions, catalogue number 680. Frozen sections were fixed in cold acetone at $20^{\circ} \mathrm{C}$ for $5 \mathrm{mins}$, and then the slides were air dried. Endogenous peroxidase was inactivated by adding $3 \% \mathrm{H}_{2} \mathrm{O}_{2}$ for 15 min. and then washed twice by phosphate buffered saline (PBS). Blocking of non-specific antigens was done for $30 \mathrm{~min}$, and then washed in PBS.

Sections were incubated with the primary antibody at room temperature for 1 hour (including +ve \& -ve control), then washed 3 times with Trissaline $\mathrm{pH} \mathrm{7.4,} \mathrm{containing} 2 \%$ fetal bovine serum (FBS ) for $5 \mathrm{~min}$./each.

Labeling of the antibody (avidin-biotin $\mathrm{ABC}$ technique) was done by adding reagent (1C) for $30 \mathrm{~min}$ and washed in Tris-saline, then adding reagent- 2 for 30 min. and washed in Tris-saline.

The chromogen substrate was prepared and added for 5-30 min. depending on the control slide. The slides were then washed in distilled water for $5 \mathrm{~min}$. and counterstained with haematoxylin. Slides were washed under tap water then distilled water 3 times, and finally covered with aquamount.

\section{Quantitative Analysis}

All slides were examined after staining by the computerized image analyzer using Optimas 6.21 software (Media Cybernetics Inc. 1998). 
The statistical analysis was carried out according to the standard statistical procedures and Student (t) test to estimate the significance of results using Microsoft Excel 2000.

\section{RESULTS}

Group-A (control group):

There were no foam cells in the intima of the arteries after peroxidase or acid phosphatase techniques. Both peoxidase and acid phosphatase activities were significantly less than the other groups (Table 1, Fig. 1, and Plate 1).

It showed a minimal (basic) expression of both ICAM-1 and VCAM-1 mainly in their endothelial lining (Table 2, Fig. 2 and Plate 2).

Group-B (Atherosclerotic group):

There was accumulation of foam cells in the subintima of the atherosclerotic animal arteries, which have high peroxidase and acid phosphatase activities (plate 1). Both peroxidase and acid phosphatase activities were significantly higher than in other groups (Table 1, Fig.1 Plate1).
The expression of the adhesion molecules (ICAM-1) is represented in plate 2. The intensity of labeling in group-B is higher than group-A (plate 2 ). The relative amount of ICAM-1 in arterial endothelium (Table 2, Figure 2) was significantly higher $(0.74 \pm 0.31)$ than control $(0.50 \pm 0.15)$ group.

The expression of the adhesion molecules (VCAM-1) was also higher on the endothelium of atherosclerotic group compared to control (plate 2). The relative amount of VCAM-1 in arterial endothelium (table 2, figure 2) was significantly higher in the atherosclerotic $(0.37 \pm 0.19)$ than control $(0.33 \pm 0.04)$ group.

Group-C (Melatonin treated atheroscl erotic group):

In both peroxidase and acid phosphatase stained sections (plate 1) the subendot helium showed no accumulation of phagocytic cells. Both peoxidase and acid phosphatase activities were signif icantly less than group-B and higher than group-A (Table1, Fig.1 and Plate1).

Table (1): Mean optical density of acid phosphatase and peroxidase enzymes in sections from all groups $(\mathrm{Gr}$. Comp. = groups compared).

\begin{tabular}{|l|l|l|l|l|l|l|l|l|}
\hline & \multicolumn{2}{|l|}{ Group-A } & \multicolumn{2}{l|}{ Group-B } & \multicolumn{2}{l|}{ Group-C } \\
\cline { 2 - 9 } & Acid Ph & Perox & Acid Ph & Perox & Acid Ph & \multicolumn{2}{l|}{ Perox } \\
\hline Mean & 0.287 & 0.384 & 0.385 & 0.536 & 0.306 & 0.189 & \\
\hline STDEV & 0.02 & 0.159 & 0.032 & 0.169 & 0.017 & & 0.426 \\
\hline Gr.Comp. & & & A:B & A:B & B:C & A:C & B:C & A:C \\
\hline P-Value & & & 0.0001 & 0.0007 & 0.00025 & 0.003 & 0.00012 & 0.002 \\
\hline
\end{tabular}


Histochemical And Immunohistochemical........

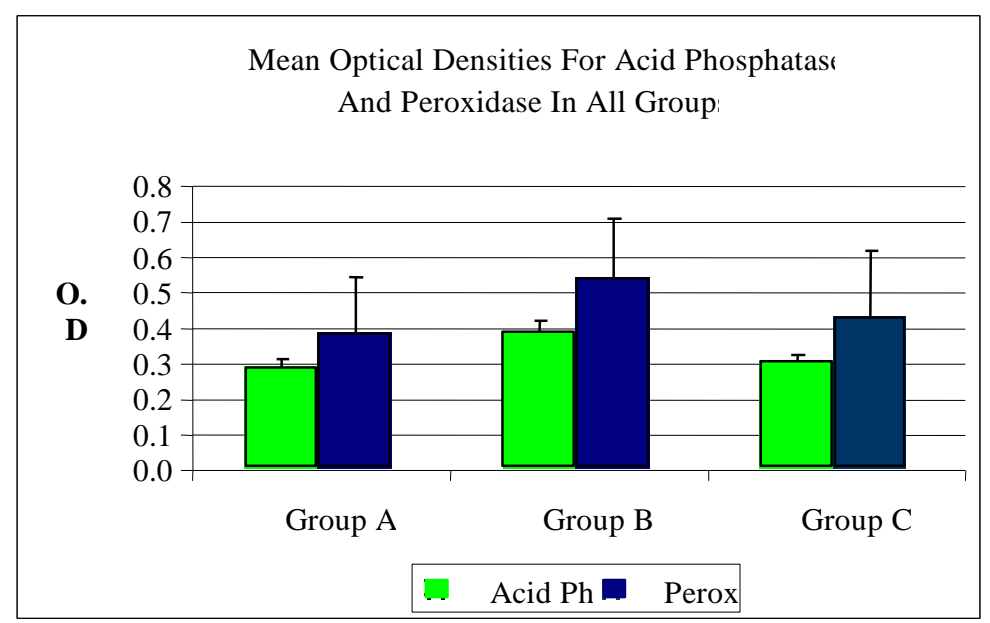

Figure (1): Mean optical density of acid phosphatase and peroxidase enzymes. The error bars represent the standard deviation.

ICAM-1 expression (table 2, figure 2, plate2) in group-C $(0.54 \pm 0.04)$ was relatively higher than control $(0.50 \pm 0.15)$. It was, however, significantly less than atherosclerotic $(0.74 \pm 0.31)$ group.

VCAM-1 expression (Table2, Fig 2 and plate 2) on the endothelium in group-C $(0.25 \pm$ 0.08 ) was less than group-A and also significantly less than group-B.

Table (2): Mean optical density of ICAM-1 and VCAM-1 expression on the endothelial surface of thoracic aorta of all groups (Gr. Comp. = groups compared)

\begin{tabular}{|l|l|l|l|l|l|l|l|l|}
\hline \multirow{2}{*}{} & \multicolumn{2}{|c|}{ Group-A } & \multicolumn{2}{c|}{ Group-B } & \multicolumn{3}{c|}{ Group-C } \\
\cline { 2 - 9 } & ICAM.1 & VCAM.1 & ICAM.1 & VCAM.1 & ICAM.1 & VCAM.1 \\
\hline Mean & 0.506 & 0.33 & 0.747 & 0.375 & 0.549 & & 0.254 \\
\hline STDEV & 0.154 & 0.048 & 0.313 & 0.196 & 0.045 & & 0.089 \\
\hline Gr.Comp. & & & A:B & A:B & B:C & A:C & B:C & A:C \\
\hline P-Value & & & $<0.00001$ & 0.013 & $<0.00001$ & 0.001 & $<0.00001$ & $<0.00001$ \\
\hline
\end{tabular}

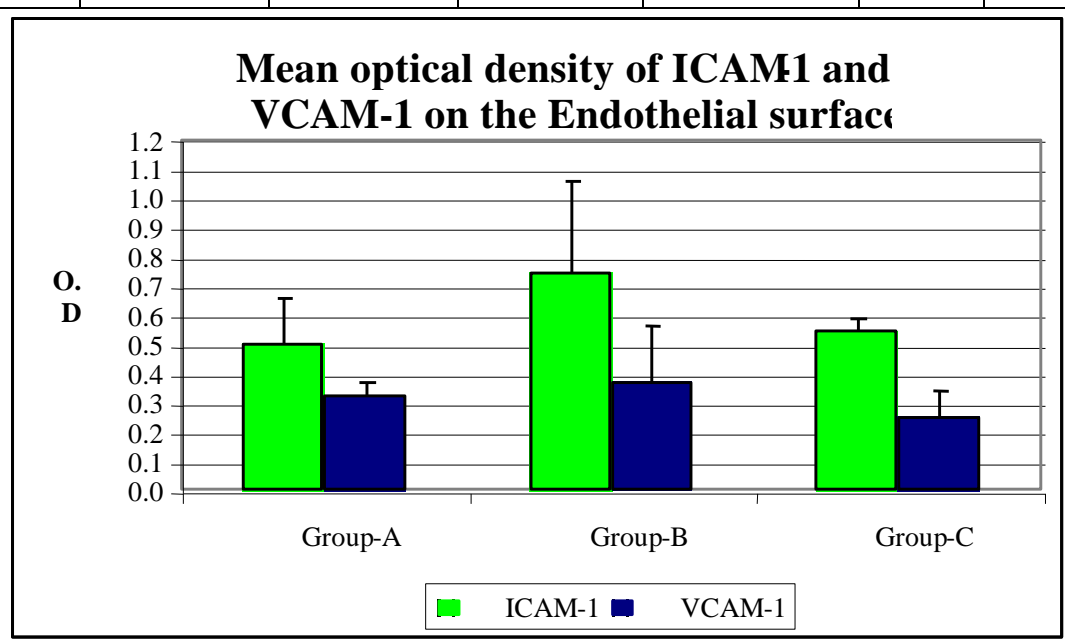

Figure (2): Mean optical density of ICAM-1 and VCAM-1 expression on the endothelial surface of thoracic aorta of different groups. The error bars represent the standard deviation. 


\section{Peroxidase}
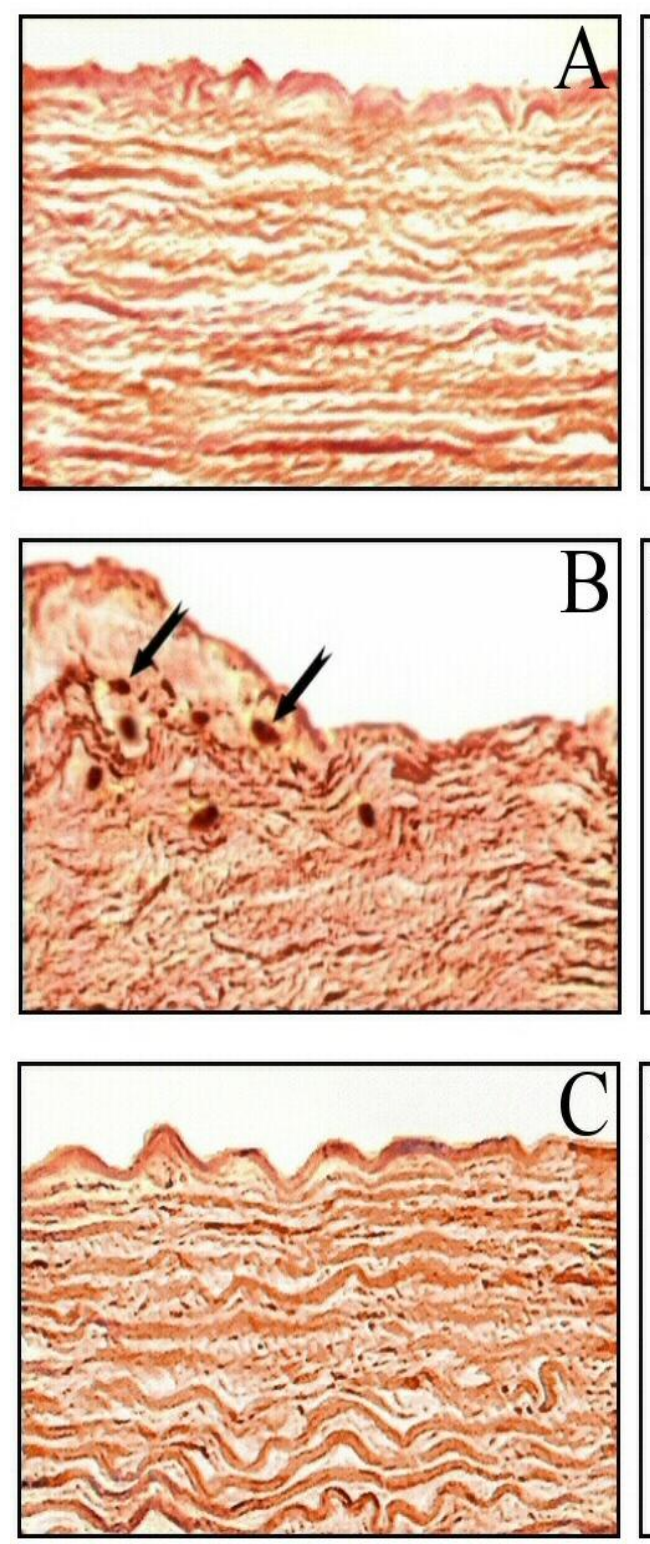

Acid Phosphatase
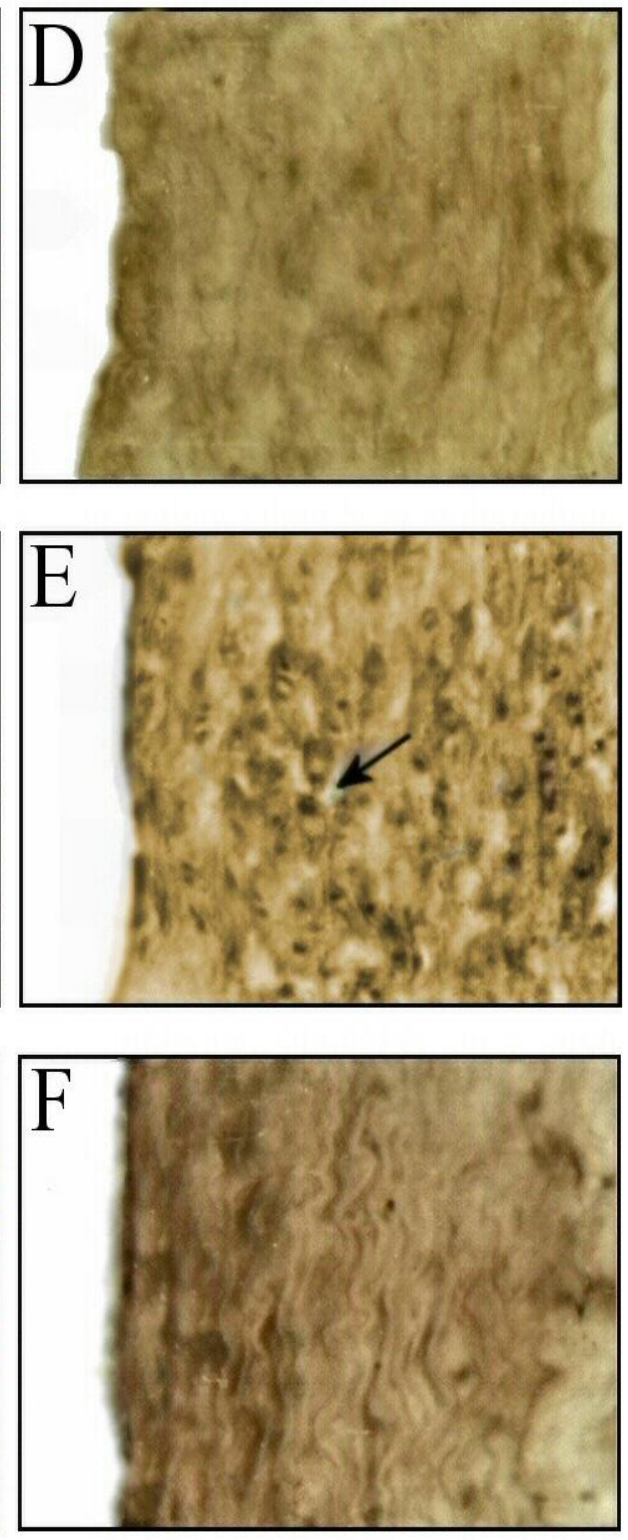

Plate 1: On the left side (Peroxidase reaction $x$ 500), figure-A,B and $C$ represent sections from group-A, $\mathrm{B}$ and $\mathrm{C}$ respectively. Note the marked accumulation of phagocytic cells which have high enzymatic activity in the subendothelium of group-B only (arrow). On the right side (Acid phosphatase reaction $x$ 500), figure-D,E and $\mathrm{F}$ represent sections from group-A, $B$ and $C$ respectively. Note that accumulation of foam cells is only seen in group-B (Figure-E). 

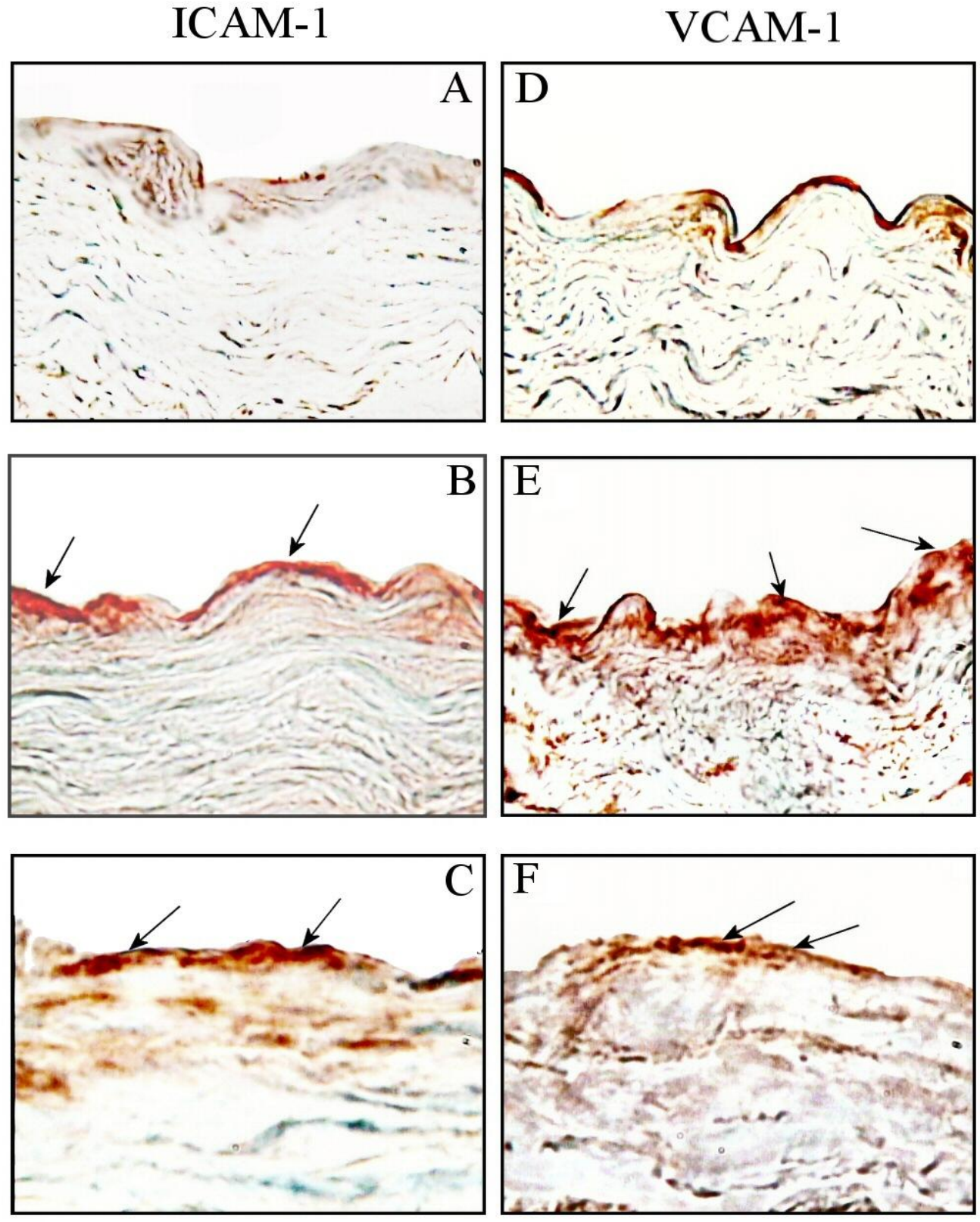

Plate 2: On the left side (ICAM-1 expression by immunoperoxidase x1000), figure-A,B and $\mathrm{C}$ represent sections from group-A, $\mathrm{B}$ and $\mathrm{C}$ respectively. Note the high expression of ICAM-1 in group B (Arrows). On the right side (VCAM-1 expression by immunoperoxidase $\mathrm{x} 1000$ ) figure-D, E and $\mathrm{F}$ represent sections from group-A, B and C respectively. Note the high expression of VCAM-1 in group B compared to other group (Arrows).

\section{DISCUSSION}

Several theories have been proposed for the pathogenesis of ather osclerosis. However, all of these theories suggested that lipid peroxida tion has a primary effect on the onset of atherosclerosis (Chisolm, 1991; Navab,

etal., 1995; Berliner \& Heinecke, 1996; Steinberg \& Lewis, 1997). Antioxidants, such as melatonin, were shown to exert a protective effect from atherosclerosis by prevention of lipid peroxidation (Carr, et al., 2000). The first component 
of the blood vessel affected by atherosclerosis is the endothelial lining. Abnormalities of the endothelium are induced by certain lipids, peroxidants, and inflammatory cytokines (Hennig \& Toborek, 2001).

In the present study, induction of atherosclerosis resulted in aggregation of macrophages in the aortic subintimal areas of the atherosclerotic group and increased the expression of both ICAM1 and VCAM-1 on the endothelial lining. Both features were reported as consequences of lipid peroxidation leading to atherosclerosis ( Sevanian and Hodis 1997)

The absence of macrophage aggregations in the subendothelial layer of the intima in group- $\mathrm{C}$ is probably due to the action of melatonin as an antio xidant, which protects the endothelial cells against injury. Such protection may be through inhibition of ICAM-1 expression which in turn inhibits mono cyte recruitment, infiltration and transf ormation into active macrophages in the subendothelial layer of the intima. As reported for other antioxidants (Gordon, etal., 1989; Berthou, et al., 1997; Fruchart, 1997; Kirchgassler, et al., 1998; Packard, 1998; Hennuyer, et al., 1999; Poulter, 1999; Krempf, et al., 2000), melatonin may affect peroxi dation of circulating lipid leading to prevention of its phagocytosis.

Expression of ICAM-1 on the endothelial cells at certain sites may be related to complex hemodynamics in these regions. Hemodynamics may increase local permeability or transport of lipoproteins by endothelium. They promote lipoprotein retention in the intima. Local oxidation of lipoproteins trapped in the intima may generate soluble factors that induce endothelial adhesion molecule expression. Introdu ction of shear stress can activate various endothelial cell signal transduction pathways (Ishida, et al., 1997; Bhullar, et al., 1998). They influence the expression of adhesion molecules (Nagel, et al., 1994).

The localized expression of ICAM-1 in aortic endothelium of normal animals may provide a milieu for atherosclerotic lesion formation. It may result in occasional recruitment of monocytes into the intima. A potential mechanism for this is production of chemokines and inflammatory cytokines during engulf ment of oxidized lipoproteins and transformation into foam cells (Malinauskas, et al., 1995).

The endothelial expression of ICAM-1 in group-B was significantly increased when compared to group-A. This can be explained by LDL oxidation in atheros clerosis which enhances the expression of ICAM-1 that influences the adhesion and endothelial transmigration of monocytes (Cominacini, et al., 1997).

Oxidized LDL stimulates the expression of the peroxisome proliferator-activated receptor $\gamma$ (PPAR $\gamma)$ in macrophages. Immunocytoche mical localization of PPAR and $\mathrm{Ox}$ LDL in macrophages (and probably also in endothelial cells) of human atherosc lerotic lesions suggested that Ox LDL also promotes expression of this nuclear transcription factor which enhances ICAM-1 expression by end -othelial cells (Ricote, et al., 1998).

Treatment of rabbits with high cholesterol diet and melatonin in groupC significantly decreased ICAM-1 endothelial expression in thoracic aorta compared to group-B. Melatonin seems to inhibit monocyte adhesion by increasing the resistance of LDL to oxidation (Cominacini, et al., 1991; Esterbauer, et al., 1989).

The endothelial expression of VCAM-1 in group-B was significantly increased compared to group-A. This can be explained by the fact that some 
byproducts of LDL oxidation, such as lysophosphatidyl choline, increases the expression of VCAM-1 by endothelial cells in atherosclerosis (Khan, et al., 1995; Kume, et al., 1992 ; Marui, et al., 1993). The induced expression of VCAM-1 is largely dependent on synthesis of new mRNA and protein. There are apparently no storage forms of VCAM-1 (Pober, et al., 1986).

Treatment of rabbits with high cholesterol diet and melatonin signify cantly decreased VCAM-1 endothelial expression compared to group-B. Similar results were obtained by Fruebis, et al., 1999 as due to the antio xidant effect of vitamin E. Therefore, melatonin may decrease endothelial monocyte adhesion by down-regulating expression of VCAM-1 which was proposed for other antioxidants (Ferns, et al., 1993; Kaneko, et al., 1996). As an antioxidant, melatonin may also inhibit monocyte adhesion by supp ressing nuclear factor NF- $\mathrm{KB}$ mobiliz ation and the induction of VCAM-1 in endothelial cells stimulated by tumor necrosis factor (TNF) (Marui, et al., 1993; Weber, et al., 1994). NF-кB activation by TNF was found to be controlled by reactive oxygen interm ediates (ROIs) (Satriano, et al., 1993).

In conclusion, the present study suggests that melatonin administration ameliorates signs of atherosclerosis in high cholesterol-fed rabbits. Its effect may be due to its antioxidant action. However, it may also act as hormone supplement, since decreased night-time level of melatonin were reported in patients with coronary artery disease (Sakotnik, etal., 1999). Further studies are needed, however, to evaluate the effect of melatonin administration in human atherosclerosis clinically.

\section{REFERENCES}

1. Beetens J.R., M.C. Coene, A. Verheyen, L. Zonnekeyn and A.G. Herman (1984): Influence of vitamin $\mathrm{C}$ on the metabolism of arachidonic acid and the development of aortic lesions during experimental atherosc lerosis in rabbits, Biomed. Biochim. Acta 43: S273-S276.

2. Bellizzi M.C., M.F. Franklin, G.G. Duthie and W.P. James(1994): Vitamin E and coronary heart disease: the European paradox, European $J$. Clin. Nutr. 48: 822-831.

3. Berliner J.A. and Heinecke J.W. (1996): The role of oxidized lipoprot eins in atherogenesis. Free Rad. Biol. Med. 20:707-727.

4. Berthou L.; Fruchart J.C. and Gelland D.H. (1997): Opposite regul ation of human versus mouse apolipop rotein A-I by fibrates in human apolipoprotein A-I transgenic mice. J. Clin. Invest., 11:2408-2416.

5. Bhullar I.S.; Li Y-S; Miao H.; Zandi E.; Kim M.; Shjy JY-J. and Chien S. (1998): Fluid shear stress activation of IкB Kinase is integrin-dependent. J. Biol. Chem. 273: 30544-30549.

6. Bocan T.M., S.B. Mueller, E.Q. Brown, P.D. Uhlendorf, M.J. Mazur and R.S. Newton(1992): Antiathero sclerotic effects of antioxidants are lesion-specific when evaluated in hypercholest -erolemic New Zealand white rabb -its, Exp. Molec. Pathol. 57: 70-83.

7. Brugger P., Marktl W., Herold M. (1995): Impaired nocturnal secre -tion of melatonin in coronary heart disease. Lancet 346 (8985):1299-1307.

8. Carleton H. (1980): Histological Technique. Fifth edition. Oxford Medical Publications. Revised and Rewritten by R.A.B. Drury and E.A. Wallington, U.S.A:120-127.

9. Carr A.C.; Mc Call M.R. and Frei B. (2000): Oxidation of LDL by myelope roxidase and reactive nitrogen species: 
reaction pathways and antioxidant protection. Arterioscler. Thromb. Vasc. Biol. (United States), 20 (7):1716-1723.

10. Chisolm G.M. (1991): Antioxidants and atherosclerosis: a current asses sment. Clin. Cardiol. 14:125-130.

11. Cominacini L.; Garbin U.; Pasini A.F.; Davoli A.; Campagnola M.; Contessi G.B.; Pastorino A.M.; and Lo Cascio V. (1997): Antioxidants inhibit the expression of intercellular adhesion molecule-1 and vascular cell adhesion molec -ule-1 induced by oxidized LDL, on human umbilical vein endothelial cells. Free Radical Biol. Med. 22:117-127.

12. Daugherty A., B.S. Zweifel and G. Schonfeld(1989): Probucol attenu -ates the development of aortic atherosc lerosis in cholesterol-fed rabbits, Brit. J. Pharmacol. 98: 612-618.

13. Esterbauer H.; Rotheneder M.; Striegl G.; Waeg; G.; Ashy A.; Sattier W. and Jurgens G. (1989): Vitamin E and other lipophilic antiox idants protect LDL against oxidation. Fat Sci. Technol. 91:316-324.

14. Fennessy; Julie H.; Campbell; Gordon R. and Campbell (1994): Perindopril inhibits both the devel opment of atherosclerosis in the cholesterol fed rabbit and lipop -rotein binding to smooth muscle cells in culture. Atherosclerosis 106:29-41.

15. Ferns G.A.; Forster L.; Stewart-Lee A.; Nourooz-Zadeh J.; and Anggard E.E. (1993): Probucol inhibits mononuclear cell adhesion to vascular endothelium in the chol -esterol fed rabbit. Atherosclerosis, 100: 171-181.

16. Fruchart K. (1997): Mechanism of the hypolipidemic action of fibrates. Int. J. of research and investigations on atherosclerosis and related diseases.O. S.8:2-3.

17. Fruebis j.,Mercedes S.,Diane S.,Claudio N.,and Wulf P.(1999): Inhibition of VCAM-1 expression in the arterial wall is shared by structurally different antioxidants that reduce early atherosclerosis in NZW rabbits. J . Libid Res. 40:1958-1966.
18. Gey K.F., G.B. Brubacher and H.B. Stahelin (1987): Plasma levels of antioxidant vitamins in relation to ischemic heart disease and cancer, Am. J. Clin. Nutr. 45 : 1368-1377.

19. Goodman S. Louis, Gilman Alfred (1990): The Pharmacological Basis of Therapeutics, Eighth Edition, Macmillan Publishing Company, Inc., New York, Collier Macmillan, Canada, LTD, Toronto, Bailliere Tindall, London :637-639.

20. Gordon D.J.; Probstfield J.L. and Garrisson R.J. (1989):High-density lipoprotein cholesterol and cardiov ascular disease. Four prospective American studies. Circulation 79:8-15.

21. Hennig B. and Toborek M. (2001): Nutrition and endothelial cell function: implications in atherosclerosis. Nutrition Research 21:279-293.

22. Hennuyer N.; Poulain P. and Watkins B.A. (1999): Beneficial effects of fibrates on apolipoprotein A-I metabolism occur independently of any peroxisome proliferative response. Circulation. 11; 99:18, 2445-2451.

23. Hodis H.N., A. Chauhan, S. Hashimoto, D.W. Crawford and A. Sevanian(1992): Probucol redu -ces plasma and aortic wall oxysterol levels in cholesterol fed rabbits independently of its plasma cholesterol lowering effect, Atheroscleros. 96: 125-134.

24. Hodis H.N., W.J. Mack, L. LaBree, L. Cashin-Hemphill, A. Sevanian, R. Johnson and S.R. Azen (1995): Serial coronary angiographic evidence that vitamin intake reduces progression of coronary artery atherosclerosis, JAMA 273: $1849-1854$.

25. Ishida T.; Takahashi M.; Corson M.A. and Berk B.C. (1997): Fluid shear stress mediated signal transdu ction: how do endothelial cells trans duce mechanical force into biological responses? Ann. NY Acad. Sc. 811:1224.

26. Kaneko M.; Hajashi J.; Saito I.; and Miyasaka N. (1996): Probucol down regulates E-selectin expression on cultured human vascular endothelial 
cells. Arterioscler. Thromb. Vasc. Biol., 16:1047-1051.

27. Khan B.V.; Parthasarathy S.S.; Alexander R.W. and Medford R.M. (1995): Modified low density lipopro tein augment cytokine-activated vascu lar cell adhesion molecule-1 gene expr ession in human vascular endothelial cells. J. Clin. Invest. 95:1262-1270.

28. Kirchgassler K.U.; Schmitz H. and Wulf P. (1998): Effectiveness and tolerability of 12-weeks treatment with micronized fenofibrate $200 \mathrm{mg}$ in a drug monitoring programme involving 9884 patients with dyslipidaemia. Clin. Drug. Invest., 15(3):197-204.

29. Kleinveld H.A., H.L. Hak-Lemmers, M.P. Hectors, N.J. de Fouw, P.N. Demacker and A.F. Stalenhoef, (1995): Vitamin $\mathrm{E}$ and fatty acid intervention does not attenuate the progression of atherosclerosis in Watanabe heritable hyperlipidemic rabbits, Arterioscleros. Thrombos. Vasc. Biol. 15:290-297.

30. Krempf M.; Rohmer V. and Springer T.A. (2000): Efficacy and safety of micronized fenofibrate in a randomized double-blind study comparing four doses from $200 \mathrm{mg}$ to $400 \mathrm{mg}$ daily with placebo in patients with hyper cholesterolemia. Diabetes Metabolism 26(3):184-191.

31. Kume N.; Cybulsky M.I.; and Gimbrone M.A. (1992): Lysophosphatidyl choline, a comp onent of atherogenic lipoproteins, induces mononuclear leukocyte adhesion molecules in cultured human and rabbit arterial endot -helial cells. J. Clin. Invest. 90:1138-1144.

32. Malinauskas R.A.; Hermann R.A. and Truskey G.A. (1995): The distribution of intimal white blood cells in the normal rabbit aorta. Atherosclerosis. 115:147-163.

33. Marui N.; Offermann M.K.; Swerlick R.; Kunsch; C.; Rosen C.A.; Ahmad M.; Alexander R.W. and Medford R.M. (1993): Vascular cell adhesion molecule-1 (VCAM-1) gene transcription and expression are regulated through antioxidant sensitive mechanism in human vascular endothelial cells. J. Clin. Invest. 92:1866-1874.

34. Mattar F.E. and Moustafa S.A. (1995): Effects of the water soluble antioxidant vitamin $\mathrm{C}$ on the age associated defects in the activities of carbohydrates metabolizing enzymes. Egypt. J. Med. Sci. (2), 1995 : 423-433.

35. Nagel T.; Resnick N.; Atkinson W.J.; Dewey C.F.Jr. and Gimbrone M.A.Jr. (1994): Shear stress selectively upregulates interc -ellular adhesion molecule-1 expre -ssion in cultured human vascular endothelial cells. J. Clin. Invest., 94:885-891.

36. Navab M.; Fogelman A.M. and Berliner J.A. (1995): Pathogenesis of atherosclerosis. Am. J. Cardiol. 76:18C-23C.

37. Packard C.J. (1998): Overview of fe nofibrate. Heart Eur.J. Suppl: A62-65.

38. Paget G.E. and Barnes J.M. (1964): Evaluation of drug activities and pharmacometrics toxicity test. Acad. Press. London and New York. Chap. 6:135-139.

39. Pober J.S.; Bevilacqua M.P.; Mendrick D.L.; LaPiere L.A.; Fiers W. and Gimbrone M.A.Jr. (1986): Two distinct monokines, interleukin-1 and tumor necrosis factor, indepen dently induce biosynthesis and transient expression of the same antigen on the surface of cultured human vascular endothelial cells. J. Immunol. 136: 1680- 1686.

40. Poulter N. (1999): The impact of micronized fenofibrate on lipid subfractions and on reaching HDLtarget levels in 7,098 patients with dyslipidaemia. The british J. of car diology volume 6 issue 12:682-685.

41. Pearce A. (1972): A Manual for Histological Technicians, 3rd Ed.; pp: 133-5, Little, Brown \& Co., Inc.; Boston, MA;

42. Rapola J.M., J. Virtamo, J.K. Haukka, O.P. Heininen, D. Albanes, P.R. Taylor and J.K. Huttunan (1996): Effect of vitamin $\mathrm{E}$ and _carotene on the incidence of angina 
pectoris. A randomized, double-blind, controlled trial, JAMA 275 : 693-698.

43. Ricote M.; Huang J.; Fajas L.; Li A.; Welsch J.; Witztum J.L.; Auwerx J.; Palinski W.; and Glass C.K. (1998): Expression of the peroxisome prolife rator activated receptor $\gamma$ in human atherosclerosis and regulation in macrophages by colony stimulating factors and oxidized low density lipoprotein. Proc. Natl. Acad. Sci. U.S.A. 95:7614-7619.

44. Rimm E.B., A. Klatsky, D. Grobbee and M.J. Stampfer (1996): Review of moderate alcohol consumption and reduced risk of coronary heart disease: is the effect due to beer, wine, or spirits, Brit. Med. J. 312: 731-736.

45. Sakotnik A., Liebmann P.M., Stoschitzky K., Lerchen P., Schouenstein K., Klein W., Eber B. (1999): Decreased melatonin synthesis in patients with coronary artery disease. Eur. Heart J.; 20 (18):1314-1317.

46. Satriano J.A.; Shuldiner M.; Hora K.; Xing Y. and Schlondorff D. (1993): Oxygen radicals as second messengers for expression of the monocyte chemo attractant protein, JE/MCP-1, and the monocyte colonystimulating factor, CSF-1, in response to tumor necrosis factor-alpha and immunoglobulin G. J. Clin. Invest., 92:1564-1571.

47. Sevanian Alex and Howard Hodis (1997): Antioxidants and atheroscl erosis: an overview Mini-review BioFactors 6: 385-390 385 IOS Press

48. Stampfer M.J. and E.B. Rimm (1995): Epidemiologic evidence for vitamin $\mathrm{E}$ in prevention of cardiov - ascular disease, Am. J. Clin. Nutr. 62: 1365S-1369S.

49. Steinberg D., S. Parthasarathy, T.E. Carew, J.C. Khoo and J.L. Witztum, Beyond (1989): cholest -erol: Modifications of low density lipopr otein that increase its atherogenicity, New Eng. J. Med. 320: 915-924.

50. Steinberg D. and Lewis A. (1997):Conner Memorial Lecture. Oxidative modification of LDL and atherogenesis. Circulation 95:10621071.

51. Steinberg, Daniel (2000): Is there a potential therapeutic role for vitamin $\mathrm{E}$ or other antioxidants in atheroscl erosis? Current Opinion in Lipidology 11:603-607

52. Verlangieri A.J. and M.J. Bush (1992): Effects of d-alpha-tocopherol supplementation on experimentally induced primate atherosclerosis, J. Am. Coll. Nutri. 11: 131-138.

53. Weber; C.; Erl; W.; Pietsch; A.; Strobel; M.; Loms Ziegler-Heitbrock; H.W. and Weber; P.C. (1994): Antioxidants inhibit monocyte adhesion by suppressing nuclear factor-KB mobilization and induction of vascular cell adhesion molecule-1 in endothelial cells stimulate to generate radicals. Arterioscler. Thromb. 14:1665-1673.

54. Wojcicki J., L. Rozewicka, B. Barcew-Wiszniewska, L. Samochowiec, S. Juzwiak, D. Kadlubowska, S. Tustanowski and $Z$. Juzyszyn (1991): Effect of selenium and vitamin $\mathrm{E}$ on the development of experimental ather -osclerosis in rabbits, Atheroscleros. 87: 9-16. 


\title{
دراسات هستوكيميائية وهنتوكيميائية مناعية لتأثير الميلاتونين على التى فئي الثريان الأبهر فى حالة تصلب الثرايين التجريبي فى الأرنب
}

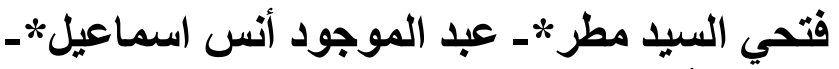

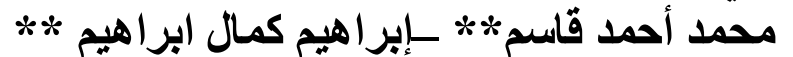

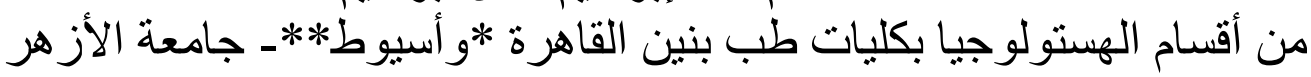

يعتبر علاج أو منع حدوث تصلب الثر ايين من التحديات التى تقابل الطب الحديث.

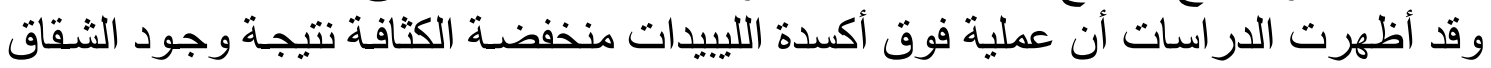

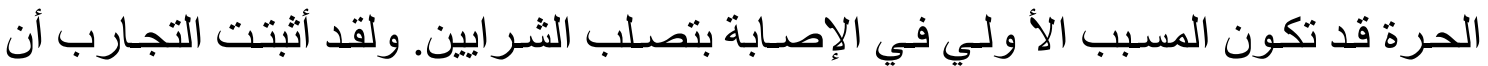

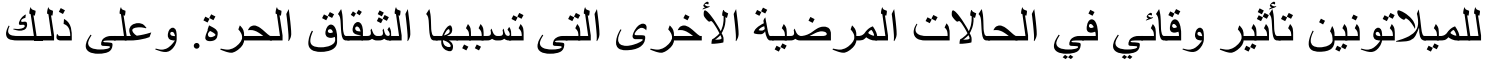

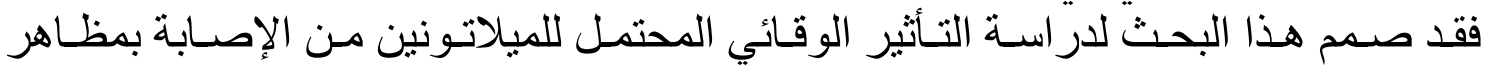

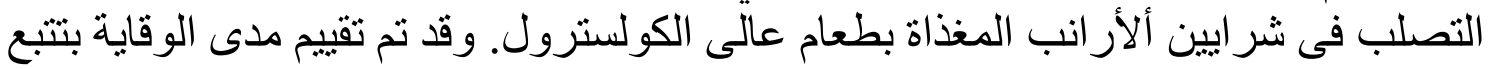

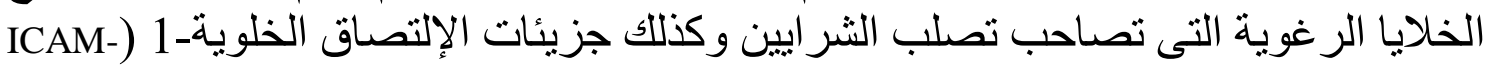

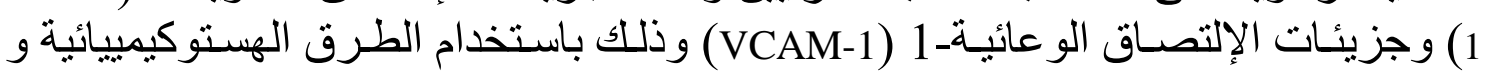
الهنتوكيمييائية المناعية الكمية.

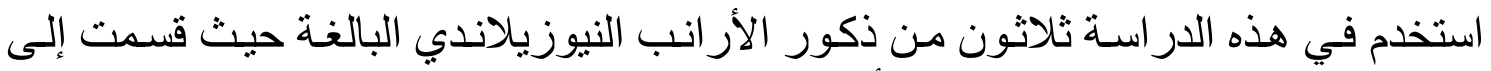

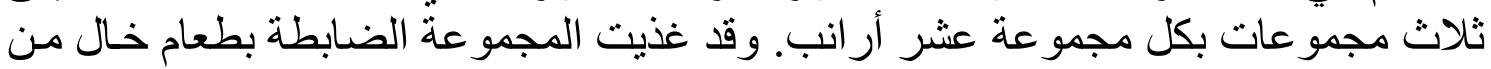

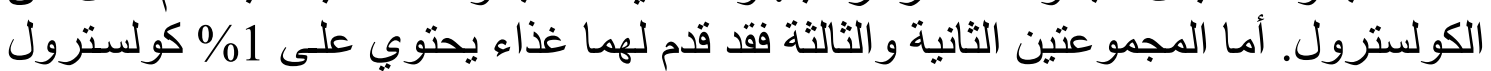

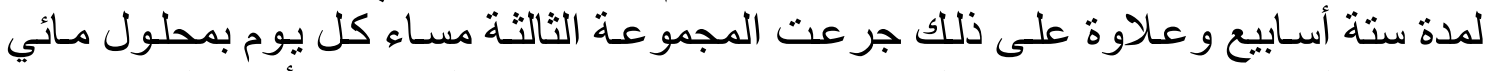

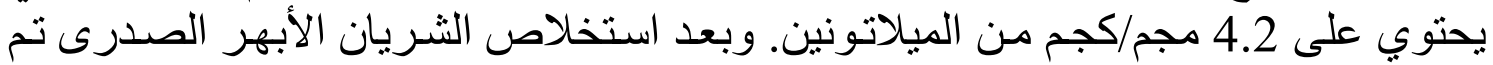

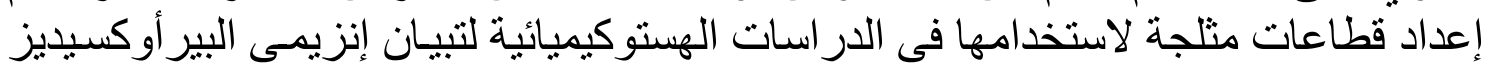

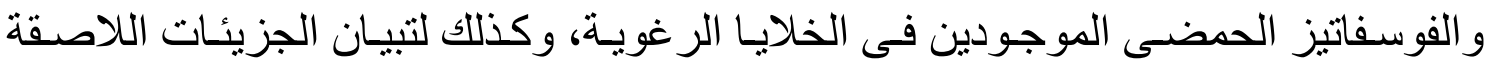

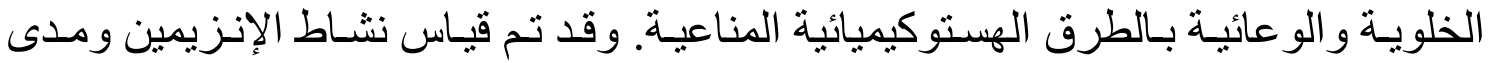

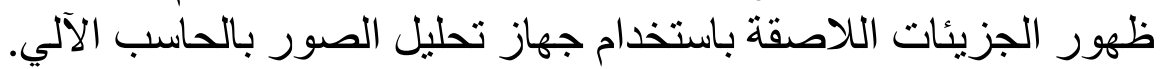

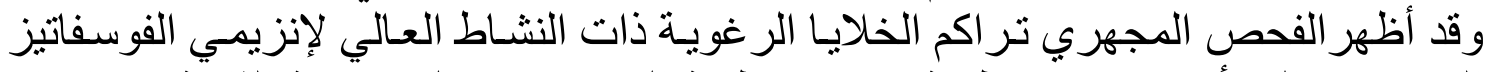

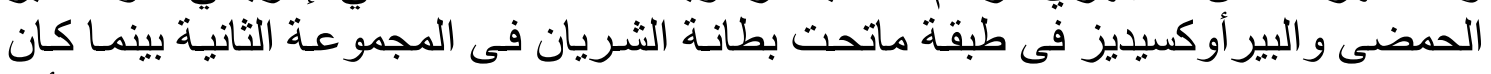

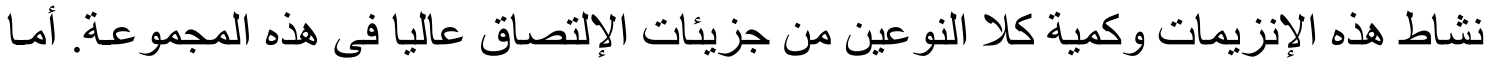

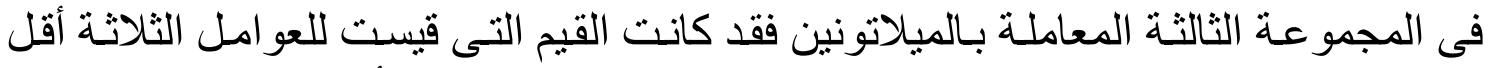

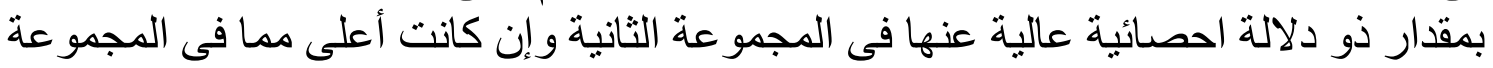
الضابطة. ويستخلص من البحث أنـه يمكن للميلاتونين أن يقوم بدور فى الوقايـة من المظــاهر التىى تصاحب تصلب الثر ايين. 